\title{
Mississippian Stratigraphic Nomenclature Revisions in Kansas
}

\author{
Evan K. Franseen ${ }^{1,3}$, Robert S. Sawin ${ }^{1,3}$, W. Lynn Watney ${ }^{1,3}$, Ronald R. West ${ }^{2,3}$, \\ Anthony Layzell ${ }^{1,3}$, and Greg A. Ludvigson ${ }^{1,3}$ \\ ${ }^{1}$ Kansas Geological Survey, 1930 Constant Avenue, Lawrence, Kansas 66047 \\ ${ }^{2}$ Emeritus Professor, Kansas State University, Manhattan, Kansas 66506 \\ ${ }^{3}$ Member, Stratigraphic Nomenclature Committee, Kansas Geological Survey
}

\begin{abstract}
This paper reviews proposed Mississippian nomenclature changes in Kansas and outlines the changes to Zeller (1968) that have been adopted by the Kansas Geological Survey. The Sedalia Dolomite is changed to the Sedalia Formation and the Northview Shale is changed to Northview Formation due to lateral lithology changes. The Short Creek Oolite Member as originally defined and described by Smith and Siebenthal (1907) at the type section in Kansas is reinstated. The Cowley Formation as originally defined and described by Lee (1940) in Kansas is reinstated. The Ste. Genevieve Limestone is placed as the basal formation of the Chesteran Stage.
\end{abstract}

\section{Introduction}

The current accepted stratigraphic guide and chart for Kansas was published 50 years ago (Zeller, 1968). Since then, papers and volumes have been published with proposed changes to the stratigraphic chart, one notable publication being Kansas Geological Survey Bulletin 230, Revision of Stratigraphic Nomenclature in Kansas (Baars, 1994). That volume contained "Revision of Mississippian Stratigraphic Nomenclature in Kansas" by Maples (1994). This paper reports changes to Zeller (1968) that are now formally adopted by the Kansas Geological Survey (KGS).

\section{Sedalia Dolomite-Sedalia Formation}

Maples (1994) recommended changing Sedalia Dolomite to Sedalia Formation (fig. 1) because of lithology changes between areas in Kansas. In accordance with the Stratigraphic Code (NACSN, 2005; Article 18 (a) - Change in lithic designation), we adopt the use of Sedalia Formation (fig. 2).

\section{Northview Shale-Northview Formation}

Maples (1994) recommended changing Northview Shale to Northview Formation (fig. 1). Because a number of studies (e.g., Weller, 1901; Lee, 1940) have documented different lithologies between areas, we adopt the use of Northview Formation in accordance with the Stratigraphic Code (NACSN, 2005; Article 18 (a)-Change in lithic designation) (fig. 2).
Short Creek Oolite Member of the Burlington Limestone-Keokuk Limestone

Maples (1994) depicted the Short Creek Oolite Member of the Keokuk Limestone on his stratigraphic chart (fig. 1). Smith and Siebenthal (1907) originally designated and described the type section for the Short Creek Oolite Member in Cherokee County, Kansas. Goebel (1968a, b) did not mention the Short Creek Oolite Member, and it is not shown on the stratigraphic chart of Zeller (1968). Goebel (1968a, b) did not provide any justification for abandonment of the term designated by Smith and Siebenthal (1907) as required by the Stratigraphic Code (NACSN, 2005; Article 20-Abandonment).

The Short Creek Oolite Member is distinct and recognized regionally in Kansas, Missouri, Oklahoma, Nebraska, and Arkansas. The geologic community has accepted and used the term in published peer-reviewed literature both before and after publication of Goebel (1968a, b) and Zeller (1968) (e.g., Moore et al., 1939; Lee, 1940; Weller et al., 1948; Lee, 1956; McKnight and Fischer, 1970; Seevers, 1975; Thompson, 1986; Kammer et al., 1990; Franseen, 2006; Ritter and Goldstein, 2012; Ramaker et al., 2015; Jayne et al., 2016). Therefore, in accordance with the Stratigraphic Code (NACSN, 2005; Article 20 (d)_-Reinstatement), we reinstate the Short Creek Oolite Member as originally defined by Smith and Siebenthal (1907) at the type section in Kansas and adopt the way in which it is depicted on the stratigraphic chart of Maples (1994) (figs. 1 and 2). 


\section{Cowley Formation}

Maples (1994) recommended resurrecting the Cowley Formation of Lee (1940) due to its distinct lithologic character compared to other Mississippian units in Kansas (fig. 1). Goebel (1968b) replaced the use of Lee's (1940) Cowley Formation with the informal term "Cowley facies" (his quotes) but did not provide sufficient justification for abandonment of the term Cowley Formation as required by the Stratigraphic Code (NACSN, 2005; Article 20Abandonment). The change appears to have been partially due to questions about the age of the Cowley Formation, as inferred from Goebel (1968a), but that is not sufficient justification for abandonment of the term Cowley Formation of Lee (1940) (NACSN, 2005; Article 13-Age; Article 22-Nature of lithostratigraphic units; Article 22 (d)-Independence from inferred geologic history; Article 22 (e)-Independence from time concepts).

As reported in Goebel (1968a, b), Thompson and Goebel (1968) used microfossils to show that the "Cowley facies" is equivalent to lithologic units from the Chattanooga Shale into the St. Louis Limestone. Subsequent work (e.g., Watney et al., 2001) corroborates the same time span for the "Cowley facies" (Cowley Formation of Lee, 1940), although the upper and lower boundaries have not yet been clearly defined.

The term Cowley Formation as proposed by Lee (1940) has been used by the geologic community since publication of Maples (1994) and appears in numerous peer-reviewed publications up to the present (Rogers et al., 1995; Montgomery et al., 1998; Watney et al., 2001; Watney et al., 2005; Watney et al., 2008; Mazzullo et al., 2009; Mitchell and Simpson, 2015). Montgomery et al. (1998) specifically pointed out the confusion with regard to stratigraphy and depositional history that has resulted from use of Goebel's (1968b) informal "Cowley facies" as a unit designation and, therefore, used the original term Cowley Formation and description as proposed by Lee (1940). In accordance with the Stratigraphic Code (NACSN, 2005; Article 20 (d)-Reinstatement), we reinstate the Cowley Formation as originally defined and described by Lee (1940) in the subsurface of Kansas and adopt the way in which it is depicted on the stratigraphic chart of Maples (1994) (figs. 1 and 2).

\section{Meramecian Stage Boundaries}

Maples (1994) proposed changes to the Meramecian Stage boundaries based on work by Maples and Waters $(1987,1988)$. Those authors moved the Ste. Genevieve Limestone from the Meramecian Stage to the Chesteran Stage based on conodont and foraminiferal zones that placed the biostratigraphic boundaries at approximately the St. Louis Limestone-Ste. Genevieve Limestone boundary and on related faunal similarity with younger Chesteran units. Thompson (2001) adopted the change and placed the Ste. Genevieve Limestone as the basal formation of the Chesteran Stage for Missouri, which is where the Ste. Genevieve type section is located. To be consistent with the change in boundary placement that has been made for other North American areas, including at the type section, we accept the change and move the Ste. Genevieve Limestone to the base of the Chesteran Stage (figs. 1 and 2).

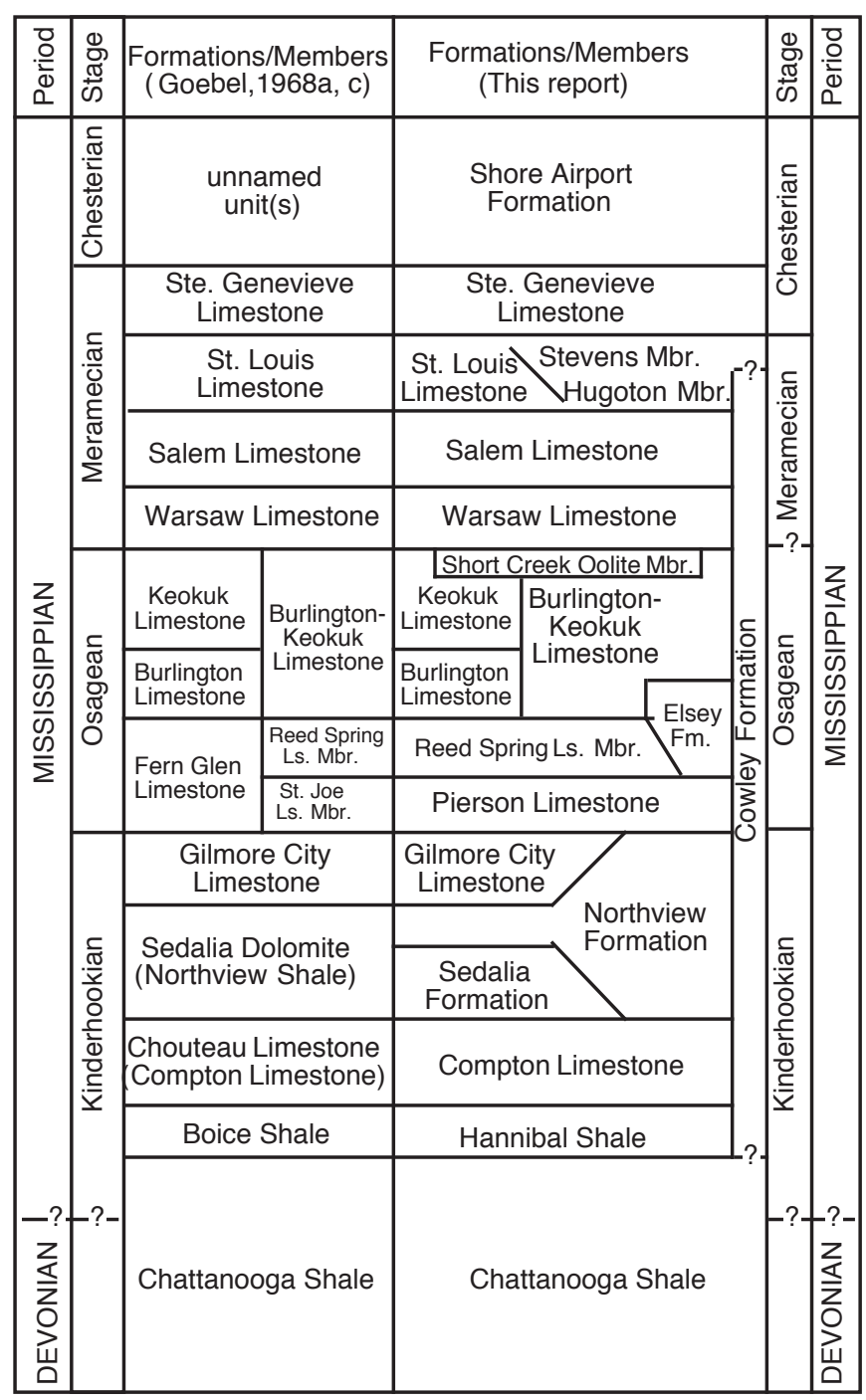

Figure 1. Mississippian stratigraphic nomenclature proposed by Maples (1994). Figure from Maples (1994). (Note: Goebel [1968c] reference in figure corresponds to Goebel [1968b] in this paper.)

\section{Summary of Formally Adopted}

Mississippian Stratigraphic Nomenclature Revisions

The following changes are adopted by the Kansas Geological Survey, and the stratigraphic chart of Zeller (1968) is modified accordingly (fig. 2).

1. Because of lateral lithologic changes between different areas, the Sedalia Dolomite is changed to Sedalia Formation on the updated stratigraphic chart of Zeller (1968).

2. The Northview Shale is changed to Northview Formation on the updated stratigraphic chart of Zeller (1968) because of lateral lithology changes between areas.

3. The Short Creek Oolite Member of the Burlington LimestoneKeokuk Limestone as defined and described by Smith and Siebenthal (1907) is reinstated and appears on the updated 
Zeller, 1968

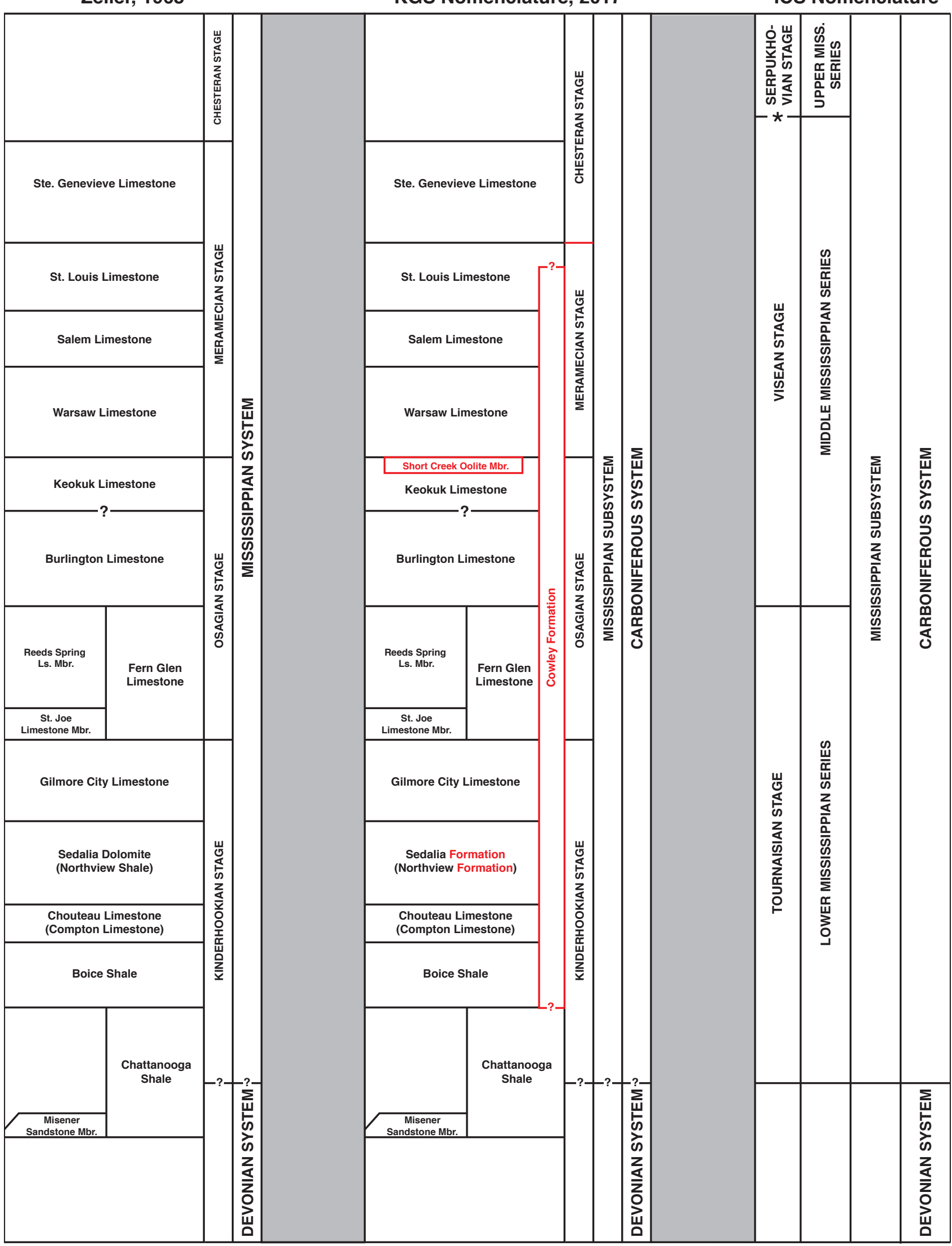

Figure 2. Mississippian nomenclature changes to Zeller (1968) that are formally adopted by the KGS. Left column: Zeller (1968). Center column: This paper, changes are highlighted in red. Right Column: International Commission on Stratigraphy (ICS) nomenclature; stage boundary with asterisk has not been ratified by the ICS/International Union of Geological Sciences (IUGS). 
stratigraphic chart of Zeller (1968) as proposed by Maples (1994).

4. The Cowley Formation as defined and described by Lee (1940) in the subsurface of Kansas is reinstated and appears on the updated stratigraphic chart of Zeller (1968) as proposed by Maples (1994).

5. The Ste. Genevieve Limestone is placed as the basal formation in the Chesteran Stage on the updated stratigraphic chart of Zeller (1968) to be consistent with the change in boundary placement in other areas of North America, including at the Ste. Genevieve type section in Missouri.

\section{KGS Stratigraphic Nomenclature Committee}

This paper was completed by current members of the Kansas Geological Survey’s Stratigraphic Nomenclature Committee, which was re-established in July 2005 to address stratigraphic issues and establish formally accepted stratigraphic nomenclature for Kansas. The Stratigraphic Nomenclature Committee is the official arbiter of stratigraphic nomenclature and issues in Kansas, subject to review by the state geologist. More information about the committee and Kansas stratigraphic nomenclature is available at http://www.kgs.ku.edu/General/Strat/index.html.

The Kansas Geological Survey recognizes Zeller (1968) as the current accepted guide and chart for Kansas. Nomenclature changes will follow the North American Stratigraphic Code (2005), and changes will conform to international stratigraphic nomenclature standards as they apply to Kansas.

\section{Acknowledgments}

We thank Tom Stanley for his constructive review and editor Rolfe Mandel, Director of the KGS and state geologist, for his review and insight. We also thank Julie Tollefson for her technical editing help.

\section{References}

Baars, D. L., compiler, 1994, Revision of stratigraphic nomenclature in Kansas: Kansas Geological Survey, Bulletin 230, 80 p.

Franseen, E. K., 2006, Mississippian (Osagean) shallow-water, midlatitude siliceous sponge spicule and heterozoan carbonate facies: An example from Kansas with implications for regional controls and distribution of potential reservoir facies: Kansas Geological Survey, Bulletin 252, part 1, 23 p. http://www.kgs.ku.edu/Current/2006/ franseen/index.html.

Goebel, E. D., 1968a, Mississippian rocks of western Kansas: American Association of Petroleum Geologists Bulletin, v. 52, p. 1,732-1,778.

Goebel, E. D., 1968b, Mississippian System; in, The stratigraphic succession in Kansas, D. E. Zeller, ed.: Kansas Geological Survey, Bulletin 189, p. 17-21.

Jayne, K. A., Chandler, A. K., and Manger, W. L., 2016, Early cementation of the Short Creek Oolite Member, Boone Formation (Osagean, Lower Mississippian), northern Arkansas: Journal of the Arkansas Academy of Science, v. 70 , art. 19, p. 105-108. http://scholarworks.uark.edu/ jaas/vol70/iss1/19.

Kammer, T. W., Brenckle, P. L., Carter, J. L., and Ausich, W. L., 1990, Redefinition of the Osagean-Meramecian boundary in the Mississippian stratotype region: Palaios, v. 5, p. 414-431.

Lee, W., 1940, The subsurface Mississippian rocks of Kansas: Kansas Geological Survey, Bulletin 33, 114 p.
Lee, W., 1956, Stratigraphy and structural development of the Salina basin area: Kansas Geological Survey, Bulletin 121, 167 p.

Maples, C. G., 1994, Revision of Mississippian stratigraphic nomenclature in Kansas; in, Revision of Stratigraphic Nomenclature in Kansas, D. L. Baars (compiler): Kansas Geological Survey, Bulletin 230, p. 67-74.

Maples, C. G., and Waters, J. A., 1987, Redefinition of the Meramecian/ Chesterian boundary (Mississippian): Geology, v. 15, p. 647-651.

Maples, C. G., and Waters, J. A., 1988, Reply (to Comment on "Redefinition of the Meramecian/Chesterian boundary (Mississippian)," by P. L. Brenckle and others): Geology, v. 16, p. 471-472.

Mazzullo, S. J., Wilhite, B. W., and Woolsey, I. W., 2009, Petroleum reservoirs within a spiculite-dominated depositional sequence: Cowley Formation (Mississippian: Lower Carboniferous), south-central Kansas: American Association of Petroleum Geologists Bulletin, v. 93, p. 1,649-1,689.

McKnight, E. T., and Fischer, R. P., 1970, Geology and ore deposits of the Picher Field, Oklahoma and Kansas: U. S. Geological Survey, Professional Paper 588, $165 \mathrm{p}$.

Mitchell, B. T., and Simpson, K., 2015, A regional re-evaluation of the Mississippi lime play, south-central Kansas: The risks and rewards of understanding complex geology in a resource play: Unconventional Resources Technology Conference (URTeC), Conference Proceedings, Paper 2154477, 7 p.

Montgomery, S. L., Mullarkey, J. C., Longman, M. W., Colleary, W. M., and Rogers, J. P., 1998, Mississippian "chat" reservoirs, south Kansas: low-resistivity pay in a complex chert reservoir: American Association of Petroleum Geologists Bulletin, v. 82, p. 187-205.

Moore, R. C., Fowler, G. M., and Lyden, J. P., 1939, Significance of the stratigraphic distribution of Mississippi Valley ore deposits; in, Contributions to a Knowledge of the Lead and Zinc Deposits of the Mississippi Valley Region, E. S. Bastin, ed.: Geological Society of America, Special Paper 24, p. 1-12, pl. 1.

NACSN (North American Commission on Stratigraphic Nomenclature), 2005, North American Stratigraphic Code: American Association of Petroleum Geologists Bulletin, v. 89, p. 1,547-1,591.

Ramaker, E. M., Goldstein, R. H., Franseen, E. K., and Watney, W. L., 2015, What controls porosity in cherty fine-grained carbonate reservoir rocks? Impact of stratigraphy, unconformities, structural setting and hydrothermal fluid flow: Mississippian, SE Kansas; in, Fundamental Controls on Fluid Flow in Carbonates, S. M. Agar and S. Geiger, eds.: Geological Society, London, Special Publications 406, p. 179-208.

Ritter, M. E., and Goldstein, R. H., 2012, Diagenetic controls on porosity preservation in lowstand oolitic and crinoidal carbonates, Mississippian, Kansas and Missouri, USA: International Association of Sedimentologists, Special Publication 45, p. 379-406.

Rogers, J. P., Longman, M. W., and Lloyd, R. M., 1995, Spiculitic chert reservoir in Glick field, south-central Kansas: The Mountain Geologist, v. 32, p. 1-22.

Seevers, W. J., 1975, Description of the surficial rocks in Cherokee County, southeastern Kansas: Kansas Geological Survey, Geology Series 1, 7 p.

Smith, W. S. T., and Siebenthal, C. E., 1907, Description of the Joplin district (Missouri-Kansas): United States Geological Survey Geologic Atlas of the United States Folio, Joplin folio, no. 148, 20 p.

Thompson, T. L., 1986, Paleozoic succession in Missouri, Part 4Mississippian System: Missouri Department of Natural Resources, Division of Geology and Land Survey, Report of Investigations, no. 70, pt. 4, 189 p. 
Thompson, T. L., 2001, Lexicon of stratigraphic nomenclature in Missouri: Missouri Department of Natural Resources, Division of Geology and Land Survey, Report of Investigations, no. 73, 371 p.

Thompson, T. L., and Goebel, E. D., 1968, Meramecian conodonts and stratigraphy of Kansas: Kansas Geological Survey, Bulletin 192, 56 p.

Watney, W. L., Franseen, E. K., Byrnes, A. P., and Nissen, S., 2005, Contrasting styles and common controls on Middle Mississippian and Pennsylvanian carbonate platforms in the northern midcontinent, U.S.A.; in, Unconventional Reservoirs Technology and StrategiesAlternative Perspectives for the Permian Basin, P. Lufholm and D. Cox, eds.: West Texas Geological Society Publication, no. 05-115, p. 221-253.

Watney, W. L., Franseen, E. K., Byrnes, A. P., and Nissen, S., 2008, Evaluating structural controls on the formation and properties of Carboniferous carbonate reservoirs in the northern midcontinent,
U.S.A.; in, Controls on Carbonate Platform and Reef Development, J. Lukasik and J. A. Simo, eds.: Society of Economic Paleontologists and Mineralogists, Special Publication 89, p. 125-146.

Watney, W. L., Guy, W. J., and Byrnes, A. P., 2001, Characterization of the Mississippian Osage chat in south-central Kansas: American Association of Petroleum Geologists, Bulletin, v. 85, p. 85-114.

Weller, J. M., Williams, J. S., Bell, W. A., Dunbar, C. O., Laudon, L. R., Moore, R. C., Stockdale, P. B., Warren, P. S., Caster, K. E., Cooper, C. L., Willard, B., Croneis, C., Malott, C. A., Price, P. H., and Sutton, A. H., 1948, Correlation of the Mississippian formations of North America: Geological Society of America Bulletin, v. 59, p. 91-196.

Weller, S., 1901, Correlation of Kinderhook formations of southwestern Missouri: Journal of Geology, v. 9, p. 130-148.

Zeller, D. E., ed, 1968, The stratigraphic succession in Kansas: Kansas Geological Survey, Bulletin 189, 81 p., 1 plate. 


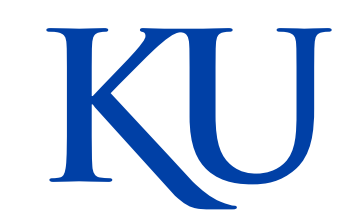

KANSAS

GEOLOGICAL

SURVEY

The University of Kansas

Current Research in Earth Sciences is a peer-reviewed publication of the Kansas Geological Survey, a division of the University of Kansas. Each annual issue of this bulletin contains short articles about earth-science research in the midcontinent (North Dakota, South Dakota, Nebraska, Kansas, Oklahoma, Minnesota, Iowa, Missouri).

As part of the KGS Bulletin series, Current Research in Earth Sciences has national and international circulation. Manuscripts are expected to be of high quality. Articles submitted to this bulletin will be published online following peer review, revision, acceptance, and editing. KGS Bulletins are archived electronically.

Submission information: http://www.kgs.ku.edu/Current/submit.html

Kansas Geological Survey

1930 Constant Avenue

The University of Kansas

Lawrence, KS 66047-3724

785.864 .3965

http://www.kgs.ku.edu/

November 2018 